\title{
PEMBELAJARAN FISIKA MELALUI DISCOVERY LEARNING DENGAN METODE EKSPERIMEN DAN DEMONSTRASI DITINJAU DARI KEMAMPUAN BERPIKIR KRITIS DAN KREATIVITAS SISWA SMK KELAS X PADA MATERI SIFAT MEKANIK BAHAN
}

\author{
Yuli Ekawati $^{1}$, Widha Sunarno ${ }^{2}$, Cari $^{3}$ \\ ${ }^{1}$ Program Studi Magister Pendidikan Sains FKIP Universitas Sebelas Maret \\ Surakarta, 57126, Indonesia \\ yuliekawati30@students.uns.ac.id \\ ${ }^{2}$ Program Studi Magister Pendidikan Sains FKIP Universitas Sebelas Maret \\ Surakarta, 57126, Indonesia \\ widhasunarno@staff.uns.ac.id \\ ${ }^{3}$ Program Studi Magister Pendidikan Sains FKIP Universitas Sebelas Maret \\ Surakarta, 57126, Indonesia \\ cari@staff.uns.ac.id
}

\begin{abstract}
Abstrak
Banyak penelitian telah dilakukan terkait penerapan discovery learning ini dalam dunia pendidikan. Menurut Hasanah (2015) ada beberapa hal yang tidak menggembirakan dari discovery learning. Penelitian ini bertujuan untuk mengetahui pengaruh dan interaksi penggunaan model Discovery Learning, metode eksperimen, metode demonstrasi, kemampuan berpikir kritis dan kreativitas terhadap hasil belajar. Metode penelitian ini adalah eksperimen. Populasi dari penelitian ini adalah siswa SMK Negeri 1 Kebonsari Madiun kelas X tahun pelajaran 2014/2015. Sampel diambil dengan teknik Cluster Random Sampling, sampel terdiri dari 2 kelas yaitu kelas X KR A dan X KR C. Kelas X KR A diberi pembelajaran dengan Discovery Learning menggunakan metode eksperimen, sedangkan X KR C diberi pembelajaran Discovery Learning dengan metode demonstrasi. Data hasil belajar kognitif, kemampuan berpikir kritis diambil menggunakan instrumen tes, data kreativitas menggunakan angket sedangkan data hasil belajar afektif dan psikomotor menggunakan lembar observasi. Data dianalisis menggunakan analisis variansi anava tiga jalan dan dilanjutkan dengan uji compare means. Hasil penelitian menunjukkan: 1) tidak terdapat perbedaan pengaruh pembelajaran discovery learning menggunakan metode eksperimen dan demonstrasi terhadap hasil belajar kognitif, afektif dan psikomotorik: 2) terdapat perbedaan pengaruh antara kemampuan berpikir kritis terhadap hasil belajar kognitif dan tidak terdapat perbedaan pengaruh antara kemampuan berpikir kritis terhadap hasil belajar afektif dan psikomotorik; 3) terdapat perbedaan pengaruh antara kreativitas siswa terhadap hasil belajar kognitif dan tidak terdapat perbedaan pengaruh antara kreativitas siswa terhadap hasil belajar afektif dan psikomotorik; 4) tidak terdapat interaksi antara metode pembelajaran dengan kemampuan berpikir kritis terhadap hasil belajar kognitif dan terdapat interaksi antara metode pembelajaran dengan kemampuan berpikir kritis terhadap hasil belajar afektif dan psikomotorik; 5) tidak terdapat interaksi antara metode pembelajaran dengan kreativitas siswa terhadap hasil belajar kognitif , afektif, psikomotorik; 6) tidak terdapat interaksi antara kemampuan berpikir kritis dengan kreativitas siswa terhadap hasil belajar kognitif, afektif, psikomotorik; 7) tidak terdapat interaksi antara metode pembelajaran, kemampuan berpikir kritis dan kreativitas siswa terhadap hasil belajar kognitif, afektif, psikomotorik.
\end{abstract}

Kata Kunci: Discovery Learning, metode eksperimen, metode demonstrasi, kemampuan berpikir kritis, dan kreativitas.

\section{Pendahuluan}

Kemajuan suatu negara dapat diukur dari kemajuan pendidikan di negara tersebut. Dalam berbagai media massa dan elektronik sering dikemukakan mutu pendidikan Indonesia tergolong rendah. Berdasarkan data dari Education For All Global Monitoring Report 2012 yang dikeluarkan oleh UNESCO, pendidikan Indonesia berada di peringkat ke64 untuk pendidikan di seluruh dunia dari 120 negara. Data Education Development Index 
(EDI) Indonesia, pada 2011 Indonesia berada di peringkat ke-69 dari 127 negara.

Perkembangan dunia pendidikan di Indonesia dari tahun ke tahun mengalami perubahan seiring dengan tantangan dalam menyiapkan sumber daya manusia yang berkualitas dan mampu bersaing di era global. Salah satu permasalahan yang dihadapi oleh bangsa kita adalah masih rendahnya kualitas pendidikan pada setiap jenjang.

Rendahnya mutu pendidikan itu terlihat dari rendahnya hasil belajar yang diperoleh siswa, termasuk di bidang studi fisika. Kenyataan ini sesuai dengan hasil studi pendahuluan peneliti dengan melakukan pengamatan kepada guru fisika diperoleh data hasil belajar fisika siswa yang pada umumnya masih rendah dibawah KKM. Hal ini terjadi disebabkan karena guru masih melakukan pola pengajaran yang sama meskipun kurikulum yang dipakai di sekolah sudah berganti. Pola pengajaran tersebut antara lain sistem pembelajaran yang memposisikan guru sebagai pusat segala informasi dan siswa sebagai objek (Teacher Center Learning), pemberian tugas dan tanya jawab di kelas.

Kegiatan belajar siswa di sekolah bertujuan membawa siswa menuju ke keadaan yang lebih baik dari segi kognitif, afektif dan psikomotornya yang bersifat permanen. Hasil dari pembelajaran yang bersifat permanen membuat guru harus benar-benar mempersiapkan pembelajaran dengan baik, agar tidak terjadi kesalahan konsep. Pembelajaran fisika di SMK harus bisa diaplikasikan ke dalam materi produktif sesuai dengan jurusan yang diambil. Oleh karena itu, siswa sering mengalami kesulitan dalam belajar fisika. Perpaduan konsep dan teori yang saling berkaitan ditambah lagi materi bersifat komplek, siswa harus memiliki kreativitas yang baik.

Konsep pada pembelajaran fisika di SMK perlu ditanamkan dengan kuat agar siswa tidak mengalami kesulitan dalam mengaplikasikan nya sesuai dengan program keahlian yang diampu. Pembelajaran fisika lebih baik dikemas dalam pembelajaran yang menekankan pada konsep dan melatih siswa berpikir kritis pada materi yang bersifat kompleks, sehingga siswa bisa menjadi tertarik dalam mempelajari fisika.

SMK Negeri 1 Kebondari Madiun merupakan salah satu sekolah kejuruan di kabupaten Madiun. Siswa yang masuk di SMK Negeri 1 Kebonsari mempunyai kemampuan di bidang akademik ataupun nonakademik yang berbeda-beda. Hasil ulangan harian merupakan salah satu cara untuk melihat keberhasilan proses pembelajaran.

Hasil pengamatan yang dilakukan saat pembelajaran berlangsung diperoleh penyebab hasil fisika rendah yaitu kurang seriusnya siswa dalam mengikuti pelajaran, siswa cenderung ada yang tidak memperhatikan saat pelajaran, masa bodoh, dan kurangnya motivasi untuk belajar. Sikap siswa yang seperti itu sangat mempengaruhi ketidaktercapaian tujuan pembelajaran dan menjadikan siswa mengalami kegagalan dalam belajar.

Masalah-masalah tersebut dapat diselesaikan dengan guru harus mengetahui kemampuan masing-masing siswa. Untuk mengetahui lebih dalam masing-masing kemampuan siswa, guru dapat menggunakan tes kemampuan berpikir yang sesuai dengan pembelajaran fisika seperti kemampuan berpikir kritis dan kreativitas. Dengan mengetahui kemampuan siswa terlebih dahulu, dapat membantu ketercapaian tujuan pembelajaran dengan memberikan pembelajaran khusus bagi siswa yang memiliki kemampuan berpikir rendah.

Guru harus mempersiapkan pembelajaran dengan model atau metode yang disesuaikan dengan materi pembelajaran fisika. Model dan metode yang dipilih ditekankan dapat memberi pembelajaran yang bermakna pada siswa sehingga dapat membantu ingatan siswa dalam jangka watu yang panjang. Pembelajaran fisika yang materinya bersifat abstrak dan susah dipahami harus dikemas dengan pembelajaran yang menyenangkan. Penggunaan model Discovery Learning siswa diberi stimulus permasalahan sebelum memulai pembelajaran. Permasalahan yang diberikan guru mengarahkan kreativitas siswa pada materi yang akan diajarkan. Siswa memberi asumsi-asumsi jawaban dari 
permasalahan tersebut dapat dibuktikan dengan suatu eksperimen ataupun demonstrasi. Dengan menggunakan metode eksperimen dan metode demonstrasi siswa menemukan sendiri konsep dari materi fisika yang diajarkan sehingga dapat mengalami proses eksperimen ataupun mengetahui secara langsung suatu proses dengan demonstrasi. Siswa dapat mengembangkan pemikiran serta kreativitas mereka, selain itu juga dapat menjadikan pembelajaran tersebut menjadi bermakna dan diingat dalam jangka waktu yang panjang.

Pembelajaran yang dikemas dengan menyenangkan oleh guru dapat membuat siswa menjadi lebih tertarik untuk belajar fisika. Saat diajak untuk eksperimen dan melihat suatu demonstrasi, siswa akan lebih antusias dalam pembelajaran. Ketertarikan siswa saat proses pembelajaran juga akan berpengaruh pada hasil belajar siswa.

Pembelajaran yang menekankan pada pembelajaran siswa aktif dalam menemukan konsep sendiri diantaranya adalah metode discovery (Kemendikbud, 2013). Pembelajaran discovery (discovery learning) merupakan suatu model pembelajaran yang dikembangkan oleh J. Bruner berdasarkan pada pandangan kognitif tentang pembelajaran dan prinsipprinsip konstruktivis (Depdiknas, 2005). Siswa belajar melalui keterlibatan aktif dengan konsep-konsep dan prinsip-prinsip, dan guru mendorong siswa untuk mendapatkan pengalaman dengan melakukan kegiatan yang memungkinkan mereka menemukan konsep dan prinsip-prinsip untuk diri mereka sendiri (Slavin, 1994).

Di dalam discovery learning siswa didorong untuk belajar sendiri secara mandiri, sebagaimana diungkapkan oleh Ilahi (2012: 30). Pada dasarnya discovery learning tidak jauh berbeda dengan pembelajaran inquiry, namun pada discovery learning masalah yang diperhadapkan kepada siswa semacam masalah yang direkayasa oleh guru, sehingga siswa tidak harus mengerahkan seluruh pikiran dan keterampilannya untuk mendapatkan temuantemuan di dalam masalah itu melalui proses penelitian (Kemendikbud, 2013).

Banyak penelitian telah dilakukan terkait penerapan discovery learning ini dalam dunia pendidikan. Menurut Hasanah (2015) ada beberapa hal yang tidak menggembirakan dari discovery learning diantara: menyulitkan bagi siswa yang membutuhkan belajar secara lebih terstruktur, potensi terbentuknya miskonsepsi, dan kemungkinan kegagalan guru mendeteksi miskonsepsi dan masalah-masalah belajar siswa.

Berdasarkan uraian masalah di atas, maka perlu dilakukan penelitian pembelajaran discovery learning menggunakan metode eksperimen dan demonstrasi ditinjau dari kemampuan berpikir kritis dan kreativitas siswa.

\section{Metode Penelitian}

Populasi dalam penelitian ini adalah siswa kelas X SMK Negeri 1 Kebonsari Madiun tahun pelajaran 2014/2015 yang terdiri dari 11 kelas dengan 4 jurusan dan jumlah siswa sebanyak 385. Teknik pengambilan sampel dalam penelitian ini menggunakan teknik cluster random sampling. Metode penelitian yang digunakan adalah penelitian eksperimen yang bertujuan untuk mengetahui pengaruh dan interaksi antara suatu variabel terhadap variabel lainnya. Penelitian ini bersifat eksperimental dengan rancangan data penelitian disajikan dalam desain faktorial $2 \times 2 \times 2$ dengan teknik analisis varians (Anava).

Instrumen yang digunakan berupa silabus, RPP dan instrumen pengambilan data berupa tes, angket dan lembar observasi. Instrumen bentuk tes untuk mengukur hasil belajar kognitif dan kemampuan berpikir kritis. Instrumen bentuk tes menggunakan tes pilihan ganda untuk soal kognitif dan kemampuan berpikir kritis. Angket digunakan untuk mengukur kreativitas siswa dan lembar observasi digunakan untuk mengukur hasil belajar afektif dan psikomotorik pada saat penelitian.

Uji validasi instrumen dilakukan oleh ahli sebelum diujicobakan. Setelah uji coba instrumen hasil belajar kognitif, kemampuan berpikir kritis diuji validitas, reliabilitas, taraf kesukaran dan uji daya pembeda soal 
sedangkan untuk kreativitas diuji validitas dan realibilitas.

\section{Hasil Penelitian dan Pembahasan}

Uji hipotesis menggunakan uji Anava. Untuk menganalisis data dilakukan dengan SPSS. Hasil hipotesis dirangkum dalam tabel 1.

\begin{tabular}{llllc}
\multicolumn{5}{c}{ Tabel 1. Hasil Hipotesis } \\
No. & $\begin{array}{l}\text { Hipotesis } \\
\text { dengan }\end{array}$ & $\begin{array}{l}\text { Sig. } \\
\text { Kogni-tif }\end{array}$ & $\begin{array}{l}\text { Sig. } \\
\text { Afektif }\end{array}$ & $\begin{array}{l}\text { Sig. } \\
\text { Psiko- } \\
\text { motor }\end{array}$ \\
\hline & ANAVA & & & 0,516 \\
1. & Hipotesis 1 & 0,535 & 0,871 & 0,136 \\
2. & Hipotesis 2 & 0,000 & 0,166 & 0,207 \\
3. & Hipotesis 3 & 0,001 & 0,123 & 0,011 \\
4. & Hipotesis 4 & 0,467 & 0,013 & 0,472 \\
5. & Hipotesis 5 & 0,275 & 0,091 & 0,279 \\
6. & Hipotesis 6 & 0,121 & 0,281 & 0,557 \\
7. & Hipotesis 7 & 0,325 & 0,905 & \\
\hline
\end{tabular}

Dari hasil analisis anava, jika sig. > 0,05; maka Ho diterima sedangkan jika sig. < 0,05; maka Ho ditolak. Dari Tabel 1 dapat dibahas hipotesis untuk data hasil belajar kognitif, afektif dan psikomotor sebagai berikut:

a. Hipotesis pertama, mengenai pengaruh metode pembelajaran terhadap hasil belajar kognitif, afektif dan psikomotor.

Metode pembelajaran eksperimen dan demonstrasi secara statistik menunjukkan tidak terdapat perbedaan pengaruh terhadap hasil belajar, tetapi berdasarkan hasil belajar siswa metode eksperimen dan demonstrasi memberikan konstribusi yang baik terhadap pembelajaran fisika terbukti dengan perolehan rata-rata hasil belajar siswa meningkat. Siswa juga terlibat aktif dalam pembelajaran sehingga dapat mengembangkan kemampuan dalam mengamati, bereksperimen ,dan menghubung-kan antara teori dan kenyataan. Siswa dapat melakukan pengujian kesimpulan atau pembuktian kembali konsep yang sudah ditemukan saat melakukan eksperimen. Berbeda dengan keadaan siswa sebelum menggunakan eksperimen maupun demonstrasi, siswa terlihat malas, mengantuk dan tidak ada semangat mengikuti pelajaran. Meskipun demikian masih ada siswa yang tidak memperhatikan pelajaran pada saat menggunakan metode eksperimen dan pada saat diskusi berlangsung ada siswa yang berdiskusi selain materi pembelajaran. Hal ini disebabkan karena jumlah alat yang terbatas sehingga setiap kelompok terdiri dari 5 orang, oleh karena itu kerja kelompok kurang maksimal. Siswa yang rajin mengerjakan LKS sedangkan yang lain berdiskusi sendiri diluar materi pelajaran.

Keadaan yang sama juga terjadi pada kelas demonstrasi, pada kelas demonstrasi jumlah kelompok sama dengan kelompok eksperimen yaitu setiap kelompok terdiri dari 5 orang. Berbeda dengan eksperimen, pada kelas demonstrasi hanya menggunakan satu alat yang diperagakan oleh siswa di depan kelas, sedangkan siswa yang lain mengamati. Keadaan yang terjadi pada kelas demonstrasi, ketika pembelajaran berlangsung awalnya siswa bersemangat dan serius dalam mengamati demonstrasi, tetapi beberapa siswa yang tidak bertugas mencatat hasil pengamatan melakukan kegiatan lain diluar pembelajaran, misalnya saling menganggu temannya yang mengerjakan, mengobrol di luar materi pembelajaran, asik bermain-main dengan alat.

Metode eksperimen maupun demonstrasi, keduanya meningkatkan semangat belajar siswa walaupun masih ada sebagian kecil siswa yang masih tetap tidak tertarik dengan pelajaran fisika. Walaupun siswa antusias dalam pembelajaran, namun materi pembelajaran yang diberikan belum sepenuhnya bisa dimengerti oleh siswa sehingga hasil belajar kognitif baik kelas eksperimen maupun demonstrasi tidak jauh berbeda.

Metode eksperimen maupun demonstrasi memberikan pengaruh positif kepada pembentukan sikap siswa dikarenakan banyaknya terjadi interaksi dengan teman sehingga dapat menumbuhkan nilai kepedulian antar teman sekelompok ataupun berbeda kelompok. Namun hasil penelitian menunjukkan metode pembelajaran eksperimen maupun demonstrasi tidak memberi perbedaan pengaruh terhadap hasil belajar afektif siswa. Selama kegiatan pembelajaran kelas eksperimen maupun kelas demonstrasi, terdapat langkah pembelajaran yang sama yaitu diskusi dimana siswa satu kelompok saling bertukar pikiran dan pendapat 
untuk memecahkan masalah. Sehingga metode pembelajaran eksperimen maupun demonstrasi tidak memberi perbedaan pengaruh terhadap hasil belajar afektif siswa.

$$
\text { Menurut Sagala (2007 : 220), }
$$
"ekperimen adalah percoban untuk membuktikan suatu pertanyaan atau hipotesis tertentu" dan "metode eksperimen adalah cara penyajian bahan pelajaran di mana siswa melakukan percobaan dengan mengalami untuk membuktikan sendiri suatu pertanyaan atau hipotesis yang dipelajari”. Ranah psikomotor adalah ranah yang berhubungan aktivitas fisik, misalnya; menulis, merangkai alat, memakai alat dan lain sebagainya.

Berdasarkan uraian di atas metode eksperimen memberi kontribusi yang besar terhadap hasil belajar psikomotorik. Hasil penelitian menunjukkan metode eksperimen tidak memberi perbedaan pengaruh terhadap hasil belajar psikomotorik. Hal ini disebabkan oleh berbagai faktor, tidak semua siswa melakukan percobaan sendiri karena keterbatasan alat, penilaian psikomotorik menggunakan lembar observasi sehingga peneliti harus benar-benar teliti siswa mana yang melakukan perobaan dan siswa mana yang hanya duduk-duduk saja dan tidak serius mengikuti pelajaran. Selama proses pembelajaran dan penilaian peneliti tidak dibantu oleh observer peneliti melakukan penilaian sendiri, sehingga hasil yang diperoleh kurang maksimal.

Menurut Sagala (2007 : 210), "Metode demonstrasi adalah pertunjukan tentang proses terjadinya suatu peristiwa atau benda sampai pada penampilan tingkah laku yang dicontohkan agar dapat diketahui dan dipahami oleh peserta didik secara nyata dan tiruannya". Pada kelas demonstrasi siswa yang melakukan demonstrasi saja yang menggunakan alat, sedangkan siswayang lain hanya mengamati. Oleh karena itu pada kelas demonstrasi ketrampilan siswa kurang dioptimalkan.

Roestiyah menyatakan bahwa discovery learning mampu membantu siswa untuk mengembangkan, memperbanyak kesiapan serta penguasaan keterampilan dalam proses kognitif/pengenalan siswa. Hasil penelitian ini berbeda dengan penelitian yang dilakukan Ali
Gunai Balim (2009) yang menyatakan bahwa discovery learning memberikan pengaruh terhadap hasil belajar. Begitu juga dengan penelitian yang dilakukan oleh Eni Arinawati (2014) yang menyatakan pembelajaran discovery learning memberi pengaruh terhadap hasil belajar.

b. Hipotesis kedua mengenai pengaruh kemampuan berpikir kritis terhadap hasil belajar kognitif, afektif, dan psikomotor.

Hipotesis kedua yang menyatakan terdapat perbedaan pengaruh pembelajaran fisika antara kemampuan berpikir kritis kategori tinggi dan rendah terhadap hasil belajar fisika siswa. Berdasarkan hasil keputusan uji hipotesis Ho ditolak untuk hasil belajar kognitif, Ho diterima untuk hasil belajar afektif dan psikomotorik . Hal ini dapat disimpulkan bahwa terdapat perbedaan pengaruh kemampuan berpikir kritis kategori tinggi dan rendah terhadap hasil belajar kognitif dan tidak terdapat perbedaan pengaruh kemampuan berpikir kritis kategori tinggi dan rendah terhadap hasil belajar afektif dan psikomotorik. Sehingga hal ini tidak sesuai dengan hipotesis awal yang menyatakan terdapat perbedaan pengaruh pembelajaran fisika antara kemampuan berpikir kritis kategori tinggi dan rendah terhadap hasil belajar fisika siswa.

Berdasarkan uji lanjut compare mean hasil belajar kognitif siswa, siswa dengan kemampuan berpikir kritis tinggi memiliki nilai yang lebih baik dari pada siswa dengan kemampuan berpikir kritis rendah. Siswa dengan kemampuan berpikir kritis tinggi lebih imajinatif, cepat tanggap terhadap sesuatu yang baru, merespon sesuatu yang baru dengan pertanyaan-pertanyaan yang mereka temukan dalam keseharian. Siswa dengan kemampuan berpikir kritis tinggi mempunyai keyakinan untuk menyelesaikan masalah dan memutuskan sesuatu berdasarkan sebab akibat serta alasan yang jelas. Dalam pembelajaran siswa dengan kemampuan berpikir kritis tinggi serius menerima pelajaran dan selalu merasa ingin tahu terhadap sesuatu yang baru. Sehingga siswa dengan kemampuan berpikir 
kritis tinggi memiliki nilai kognitif yang lebih baik.

Menurut Robert H. Ennis (1985 dalam Costa ed., 1985: 54) menyatakan bahwa berpikir kritis adalah berpikir reflektif yang masuk akal yang berfokus untuk memutuskan apa yang harus diyakini atau dilakukan. Kemampuan berpikir kritis merupakan faktor internal juga berpengaruh terhadap keberhasilan pembelajaran. Hasil belajar Kognitif adalah kemampuan intelektual siswa dalam berpikir, mengetahui dan memecahkan masalah. Tujuan aspek kognitif berorientasi pada kemampuan berfikir yang mencakup kemampuan intelektual yang lebih sederhana, yaitu mengingat, sampai pada kemampuan memecahkan masalah yang menuntut siswa untuk menghubungkan dan menggabungkan beberapa ide, gagasan, metode atau prosedur yang dipelajari untuk memecahkan masalah tersebut. Berdasarkan uraian diatas hasil penelitian sesuai dengan teori bahwa kemampuan berpikir kritis dapat diartikan sebagai bagian yang menunjang keberhasilan belajar kognitif siswa sehingga memiliki pengaruh yang signifikan terhadap keberhasilan belajar kognitif siswa. Hasil penelitian ini sesuai dengan penelitian yang dilakukan oleh Alice Rodrigues and Maurícia Oliveira (2014) terdapat perbedaan kinerja fisika antara siswa yang memiliki kemampuan berpikir kritis tinggi dan rendah.

Hasil penelitian menunjukkan bahwa kemampuan berpikir kritis kategori tinggi dan rendah tidak memberi pengaruh yang signifikan terhadap hasil belajar afektif dan psikomotorik. Kemampuan afektif berhubungan dengan minat dan sikap yang dapat berbentuk tanggung jawab, kerjasama, disiplin, komitmen, percaya diri, jujur, menghargai pendapat orang lain, dan kemampuan mengendalikan diri. Ranah psikomotor berhubungan dengan hasil belajar yang pencapaiannya melalui keterampilan manipulasi yang melibatkan otot dan kekuatan fisik. Ranah psikomotor adalah ranah yang berhubungan aktivitas fisik, misalnya; menulis, memukul, melompat dan lain sebagainya. Kemampuan berpikir kritis merupakan faktor internal yang melibatkan intelektual siswa sehingga tidak berpengaruh terhadap kemampuan afektif maupun psikomotorik siswa.

c. Hipotesis ketiga mengenai pengaruh kreativitas terhadap hasil belajar kognitif, afektif, dan psikomotor.

Hipotesis ketiga mengenai terdapat perbedaan pengaruh pembelajaran fisika antara kreativitas siswa kategori tinggi dan rendah terhadap hasil belajar fisika siswa. Hasil uji hipotesis Ho ditolak untuk hasil belajar kognitif, Ho diterima untuk hasil belajar afektif dan psikomotorik.. Hal ini berarti terdapat perbedaan pengaruh kreativitas kategori tinggi dan rendah terhadap hasil belajar kognitif dan tidak terdapat perbedaan pengaruh kreativitas kategori tinggi dan rendah terhadap hasil belajar afektif dan psikomotorik.

. Berdasarkan uji lanjut compare mean rata-rata hasil belajar kognitif siswa, siswa dengan kreativitas tinggi memiliki nilai yang lebih rendah dari pada siswa dengan kreativitas rendah. Kreativitas siswa tidak memberi pengaruh yang signifikan terhadap hasil belajar afektif dan psikomotorik.

Kreativitas merupakan kemampuan menyampaikan gagasan, melakukan aktivitas, mengubah pola pikir, pemecahan masalah atau mengembangkan konsep baru dengan caracara tidak konvensional, atau dapat dilakukan tidak hanya terfokus pada satu cara saja. Kreativitas belajar dapat dilihat berdasarkan aspek kognitif dan afektif. Aspek kognitif seperti kelancaran, keluwesan dan keaslian dalam pemikiran. Aspek afektif seperti rasa ingin tahu, senang mengajukan pertanyaan dan selalu ingin mencari pengalaman baru. Berdasarkan uraian tersebut terlihat bahwa kreativitas menunjang keberhasilan belajar siswa khususnya hasil belajar kognitif dan afektif.

Khabibah (2006 : 9) menyatakan bahwa salah satu konsep yang amat penting dalam bidang kreativitas adalah hubungan antara kreativitas dan aktualisasi diri. Abraham Maslow dan Carl (dalam Khabibah, 2006) menyatakan bahwa seseorang dikatakan mengaktualisasi dirinya apabila seseorang menggunakan semua bakat dan talentanya 
untuk menjadi apa yang ia mampu menjadi, mengaktualisasikan atau mewujudkan potensinya. Menurut Maslaw aktualisasi diri merupakan karakteristik yang fundamental, yaitu suatu potensial yang ada pada semua manusia saat dilahirkan, akan tetapi sering hilang, terlambat atau terpendam dalam proses pembudayaan.

Berdasarkan hasil penelitian kreativitas berpengaruh terhadap hasil belajar kognitif siswa, siswa dengan kreativitas tinggi memiliki hasil belajar kognitif lebih rendah dari siswa yang memiliki kreativitas rendah. Hal ini disebabkan karena instrumen yang digunakan untuk mengukur kreativitas siswa terbatas pada kreativitas pemikiran sedangkan kreativitas bisa dinyatakan dalam bentuk tindakan. Peneliti hanya mengukur kreativitas menggunakan angket yang seharusnya bisa lebih dioptimalkan dengan menggunakan lembar observasi sehingga kreativitas siswa dapat diukur baik secara pemikiran maupun tindakan.

Kreativitas bukan satu-satunya penentu keberhasilan kognitif siswa, ada faktor lain yang menunjang daripada keberhasilan kognitif siswa seperti intelektual siswa, lingkungan dan sarana prasarana disekolah. Hasil penelitian menunjukkan kreativitas siswa tidak memberi pengaruh yang signifikan terhadap hasil belajar afektif dan psikomotorik. Hal ini dikarenakan beberapa alasan: pertama, siswa memiliki antusias belajar yang sama baik siswa yang memiliki kreativitas tinggi maupun rendah karena sebelumnya siswa belum pernah melakukan kegiatan pembelajaran dengan menggunakan bantuan alat. Kedua, latar belakang siswa berasal dari sekolah kejuruan yang menuntut siswa untuk mengembangkan kreativitas yang dimiliki.

d. Hipotesis keempat mengenai interaksi pembelajaran Discovery Learning menggunakan metode eksperimen dan metode demonstrasi dengan kemampuan berpikir kritis terhadap hasil belajar kognitif, afektif, dan psikomotor.

Hipotesis keempat yang menyatakan terdapat interaksi antara metode pembelajaran eksperimen dan demonstrasi dengan kemampuan berpikir kritis terhadap hasil belajar fisika siswa. Hasil uji hipotesis Ho diterima untuk hasil belajar kognitif, Ho ditolak untuk hasil belajar afektif dan psikomotorik. Hal ini berarti bahwa tidak terdapat interaksi antara metode pembelajaran eksperimen dan demonstrasi dengan kemampuan berpikir kritis terhadap hasil belajar kognitif dan terdapat interaksi antara metode pembelajaran eksperimen dan demonstrasi dengan kemampuan berpikir kritis terhadap hasil belajar afektif dan psikomotorik.

Hasil penelitian menunjukkan rata-rata hasil belajar kognitif siswa dengan metode eksperimen yang memiliki kemampuan berpikir kritis tinggi memiliki pengaruh yang lebih baik terhadap hasil belajar kognitif sswa. Siswa yang mempunyai kemampuan berpikir kritis tinggi memiliki semnaat belajar yang tinggi, hal ini terlihat ketika proses pembelajaran siswa yang berpikir kritis tinggi lebih serius mengikuti pelajaran, memiliki rasa ingin tahu yang besar dan lebih aktif bertanya. Didukung dengan metode pembelajaran eksperimen dimana siswa melakukan percobaan sendiri, sehingga pengetahuan yang didapatkan oleh siswa lebih bertahan lama dan membantu siswa lebih mudah untuk memahami materi pelajaran yang disampaikan.

Hasil uji hipotess diperoleh metode demonstrasi dengan kemampuan berpikir kritis tinggi memiliki pengaruh yang lebih baik terhadap hasil belajar afektif siswa. Siswa dengan kemampuan berpikir kritis tinggi mempunyai rasa tanggung jawab yang besar, disiplin, jujur dan dapat mengendalikan diri. Hal ini terlihat selama proses pembelajaran berlangsung siswa dengan kemampuan berpikir kritis tinggi dapat menyelesaikan tugas yang diberikan sesuai dengan waktu yang diberikan.

Hasil belajar ranah afektif berhubungan dengan sikap dan minat/motivasi. Dalam metode demonstrasi siswa lebih banyak memperhatikan, membaca untuk menemukan jawaban dari masalah. Siswa mencari referensi dari buku atau internet untuk menjawab pertanyaan dari kegiatan demonstrasi, sehingga siswa yang awalnya malas membaca menjadi membaca, siswa yang awalnya tidak 
memperhatikan menjadi memperhatikan, siswa yang awalnya kurang termotivasi menjadi lebih semangat mengikuti pembelajaran.

Dalam metode demonstrasi siswa melakukan identifikasi masalah berdasarkan materi yang didemonstrasikan yaitu hukum hooke, kemudian siswa mencari sendiri jawaban dari permasalahan tersebut dan akan dicocokan dengan teori pada akhir pelajaran untuk mendapatkan kesimpulan. Salah satu indikator kemampuan berpikir kritis adalah inference (membuat inferensi/ kesimpulan). Penarikan kesimpulan dapat dilakukan dengan melakukan penalaran secara deduktif maupun induktif. Berdasarkan pernyataan diatas dapat disimpulkan bahwa antara metode demonstrasi dan kemampuan berpikir kritis memiliki pengaruh terhadap hasil belajar afektif siswa.

Uji hipotesis memperlihatkan bahwa rata-rata hasil belajar psikomotorik siswa metode eksperimen dengan kemampuan berpikir kritis rendah memiliki pengaruh yang lebih baik terhadap hasil belajar psikomotorik siswa. Pada metode eksperimen siswa belajar dengan mengalami atau mengamati sendiri suatu proses atau kejadian dan memperkaya pengalaman dengan hal-hal yang bersifat objektif dan realistis. Siswa dengan kemampuan berpikir kritis rendah terlihat kurang semangat dalam belajar karena merasa dirinya tidak bisa sehingga tidak tertarik untuk mengikuti pelajaran. Hasilnya dikelas rame, bermain-main sendiri, menganggu temannya. Dengan melakukan suatu kegiatan yaitu bereksperimen dapat mengurangi hal-hal yang dilakukan siswa diluar pembelajaran. Siswa merangkai alat sendiri kemudian melakukan eksperimen sehingga kegiatan yang dilakukan lebih mengarah kepada materi pelajaran.

Ranah psikomotor berhubungan dengan hasil belajar yang pencapaiannya melalui keterampilan manipulasi yang melibatkan otot dan kekuatan fisik. Ranah psikomotor adalah ranah yang berhubungan aktivitas fisik, misalnya; menulis, merangkai alat, memakai alat dan lain sebagainya. Metode eksperimen adalah metode mengajar di mana pengajar atau pelajar mencoba mengerjakan sesuatu serta mengamati proses dan hasil percobaan itu. Penelitian dilakukan di sekolah menengah kejuruan yang pada dasarkan menekankan unjuk kerja atau praktek dan keterampilan siswa, sehingga metode eksperimen sesuai dengan latar belakang siswa. Berdasarkan uraian di atas menunjukkan bahwa metode eksperimen memberi pengaruh yang lebik baik terhadap hasil belajar psikomotorik siswa walaupan siswa tersebut memiliki kemampuan berpikir kritis rendah.

Ika Candra Sayekti (2012) menyatakan bahwa metode pembelajaran eksperimen dan demonstrasi mengandung metode ilmiah yang erat kaitannya dengan sikap ilmiah siswa. Tinjauan kemampuan berpikir kritis merupakan komponen yang digunakan sebagai instrumen untuk mengukur kemampuan berpikir siswa yang mengacu pada ranah kognitif.

e. Hipotesis kelima mengenai interaksi pembelajaran berbasis Discovery Learning menggunakan metode eksperimen dan demonstrasi dengan kreativitas terhadap hasil belajar kognitif, afektif, dan psikomotor.

Pada hipotesis kelima mengenai terdapat interaksi antara metode pembelajaran eksperimen dan demonstrasi dengan kreativitas siswa kategori tinggi dan rendah terhadap hasil belajar fisika siswa. Hasil uji hipotesis menunjukkan bahwa tidak terdapat interaksi antara metode pembelajaran eksperimen dan demonstrasi dengan kemampuan berpikir kritis terhadap hasil belajar kognitif, afektif dan psikomotorik.

Kreativitas menurut Rongers (dalam Utami Munandar, 2009:18) mengemukakan kreativitas adalah kecenderungan untuk mengaktualisasi diri mewujudkan potensi dorongan untuk berkembang dan menjadi matang, kecenderungan untuk mengekspresikan dan mengaktifkan semua kemampuan organisme. Pada penelitian ini tidak ditemukan interaksi antara metode pembelajaran eksperimen dan demonstrasi dengan kreativitas siswa kategori tinggi dan rendah terhadap hasil belajar kognitif, afektif dan psikomotorik. Berdasarkan rata-rata nilai siswa dengan kreativitas tinggi memiliki nilai kognitif yang lebih rendah, nilai afektif dan 
psikomotorik lebih tinggi. Pada metode pembelajaran eksperimen siswa memiliki nilai kognitif, afektif dan psikomotorik siswa yang lebih baik. Berdasarkan pernyataan tersebut dapat disimpulkan antara metode pembelajaran dan kreativitas merupakan hal yang berdiri sendiri, sehingga tidak berhubungan. Kreativitas diukur menggunakan angket, siswa terkadang mengisi angket tidak bersungguhsungguh asal-asalan atau mencontek jawaban temannya sehingga mempengaruhi daripada nilai kreativitas.

Hal ini disebabkan oleh beberapa kendala, pertama; di lapangan ketika melakukan penelitian seperti tidak semua siswa yang menjadi sampel penelitian menggunakan kreativitasnya untuk menyelesaikan masalah yang dihadapi. Terkadang siswa yang kurang aktif dan pendiam karena memang ulet dan rajin belajar, sehingga memiliki nilai kognitif yang baik. Berbeda halnya dengan siswa yang sangat kreatif tetapi kurang begitu pintar.

Kedua, instrumen yang digunakan untuk mengukur kreativitas siswa adalah angket, beberapa siswa mengisi angket asal-asalan tidak disesuaikan dengan keadaan pribadi siswa. Beberapa siswa juga mengisi angket berdasarkan melihat jawaban dari teman sehingga mempengaruhi hasil dari pada kreativitas siswa.

Hasil penelitian ini berbeda dengan penelitian yang dilakukan oleh Javier A. Pulgar Neira dan Iván R. Sánchez Soto (2013) yang menyatakan korelasi tinggi antara beberapa dimensi kreativitas dan keberhasilan akademis, menunjukkan pentingnya variabel kognitif (kreativitas) dalam mengajar dan belajar ilmu pengetahuan. Menurut Javier A. Pulgar Neira dan Iván R. Sánchez Soto kreativitas merupakan variabel yang penting dalam mengajar dan belajar sains khususnya dalam mencapai keberhasilan belajar kognitif.

f. Hipotesis keenam mengenai kemampuan berpikir kritis dengan kreativitas terhadap hasil belajar kognitif, afektif dan psikomotor.

Pada hipotesis keenam mengenai terdapat interaksi antara kemampuan berpikir kritis dengan kreativitas siswa dalam belajar fisika terhadap hasil belajar fisika siswa. Hasil penelitian menunjukkan tidak terdapat interaksi antara kemampuan berpikir kritis dengan kreativitas terhadap hasil belajar kognitif, afektif dan psikomotorik.

Menurut Robert H. Ennis. Ennis (1985 dalam Costa ed., 1985: 54) menyatakan bahwa berpikir kritis adalah berpikir reflektif yang masuk akal yang berfokus untuk memutuskan apa yang harus diyakini atau dilakukan. Kreativitas adalah kemampuan seseorang untuk menghasilkan komposisi, produk atau gagasan apa saja yang pada dasarnya baru, dan sebelumnya tidak dikenal pembuatannya. Kemampuan berpikir kritis dan kreativitas merupakan faktor internal yang mempengaruhi hasil belajar siswa khususnya hasil kognitif siswa.

Kondisi intelektual juga berpengaruh terhadap hasil belajar siswa, kondisi intelektual ini menyangkut tingkat kecerdasan, bakatbakat (bakat sekolah maupun bekerja) serta kreativitas (Susilo, 2004: 82). Penelitian dilakukan di sekoalh menengah kejuruan, pemikiran siswa SMK adalah sekolah untuk bekerja. Mereka lebih fokus de dunia kerja dari pada fokus ke materi pembelajaran di sekolah. Padahal untuk mencapai kedunia kerja didukung dengan pelajaran yang didapat di sekolah. Oleh karena itu ketika siswa SMK dihadapkan pada materi-materi pembelajaran khususnya fisika mereka menanggapi tidak serius dan dikerjakan apa adanya sesuai kemampuan mereka.

Mack (2002: 7) yang penting dari kreativitas adalah proses menyusun ide sehingga membentuk sesuatu yang baru. Pendapat tersebut disempurnakan oleh Santoso (2005: 13) yang mengemukakan bahwa kreativitas adalah upaya melakukan aktivitas yang baru dan mengagumkan. Kreativitas dapat diwujudkan dalam suatu pemikiran atau suatu produk. Dalam mengukur kreativitas peniliti hanya menggunakan angket kreativitas. Ketika siswa diberikan angket kreativitas, mereka mengerjakan dengan santai dan kadang diiisi seenaknya sendiri tanpa melihat 
kondisi sebenarnya yang dialami siswa. Angket yang digunakan disini mengukur sebatas pemikiran siswa sehingga mempengaruhi dari pada hasil penelitian yang diperoleh.

g. Hipotesis ketujuh mengenai interaksi antara metode pembelajaran eksperimen dan demonstrasi, kemampuan berpikir kritis dan kreativitas siswa terhadap hasil belajar fisika siswa

Pada hipotesis ketujuh mengenai interaksi antara metode pembelajaran eksperimen dan demonstrasi, kemampuan berpikir kritis dan kreativitas siswa terhadap hasil belajar fisika siswa. Hasil uji hipotesis menunjukkan bahwa tidak terdapat interaksi antara metode pembelajaran eksperimen dan demonstrasi, kemampuan berpikir kritis dan kreativitas siswa terhadap hasil belajar kognitif, afektif dan psikomotorik.

Rata-rata hasil belajar kognitif siswa kelas demonstrasi yang memiliki kemampuan berpikir kritis tinggi dan kreativitas tinggi menunjukkan hasil yang lebih baik. Dalam metode demonstrasi siswa mengamati suatu fenomena sehingga lebih mengembangkan pemikiran siswa untuk memunculkan ide-de baru dari hasil pengamatan siswa. Kelas demonstrasi rata-rata hasil belajar afektif yang memiliki kemampuan berpikir kritis tinggi dan kreativitas tinggi memperoleh hasil afekrif yang lebih baik. Kelas demonstrasi rata-rata hasil belajar psikomotorik yang memiliki kemampuan berpikir kritis tinggi dan kreativitas tinggi memperoleh hasil psikomotorik yang lebih baik.

Pada kelas eksperimen siswa memiliki nilai rata-rata kognitif yang lebih rendah untuk kriteria kemampuan berpikir kritis rendah dan kreativitas tinggi, nilai rata-rata afektif dan psikomotorik yang lebih tinggi untuk kriteria kemampuan berpikir kritis tinggi dan kreativitas tinggi maupun rendah. Hal ini tidak sesuai dengan hipotesis awal yang menyatakan terdapat interaksi antara metode pembelajaran eksperimen dan demonstrasi, kemampuan berpikir kritis dan kreativitas siswa terhadap hasil belajar fisika siswa. Hal ini dikarenakan karena beberapa faktor baik internal maupun eksternal dari dalam diri siswayang dapat mempengaruhi mereka untuk mendapatkan prestasi yang lebih baik. Faktor-faktor tersebut meliputi, pendekatan pembelajaran, metode pembelajaran, kemampuan berpikir kritis dan kreativitas siswa yang digunakan dalam penelitian ini., serta msih banyak keterbatsan dalam penelitian sehingga peneliti tidak dapat mengontrol faktor-faktor diluar kegiatan pembelajaran.

\section{Kesimpulan dan Rekomendasi}

Hasil penelitian ini dapat disimpulkan: 1) tidak terdapat perbedaan pengaruh pembelajaran Discovery Learning menggunakan metode eksperimen dan demonstrasi terhadap hasil belajar kognitif, afektif dan psikomotorik: 2) terdapat pengaruh antara kemampuan berpikir kritis terhadap hasil belajar kognitif dan tidak terdapat pengaruh antara kemampuan berpikir kritis terhadap hasil belajar afektif dan psikomotorik; 3) terdapat pengaruh antara kreativitas siswa terhadap hasil belajar kognitif dan tidak terdapat pengaruh antara kreativitas siswa terhadap hasil belajar afektif dan psikomotorik; 4) tidak terdapat interaksi antara metode pembelajaran dengan kemampuan berpikir kritis terhadap hasil belajar kognitif dan terdapat interaksi antara metode pembelajaran dengan kemampuan berpikir kritis terhadap hasil belajar afektif dan psikomotorik; 5) tidak terdapat interaksi antara metode pembelajaran dengan kreativitas siswa terhadap hasil belajar kognitif , afektif, psikomotorik; 6) tidak terdapat interaksi antara kemampuan berpikir kritis dengan kreativitas siswa terhadap hasil belajar kognitif, afektif, psikomotorik; 7) tidak terdapat interaksi antara metode pembelajaran, kemampuan berpikir kritis dan kreativitas siswa terhadap hasil belajar kognitif, afektif, psikomotorik.

Dalam rangka turut menyumbangkan pemikiran yang berkenaan dengan peningkatan hasil belajar fisika disarankan kepada tenaga pendidik perlu mempersiapkan secara matang perangkat pembelajaran yang sesuai dengan pembelajaran. Kepada siswa dapat meningkatkan kemampuan berpikir kritis dan kreativitas sehingga dapat mempermudah 
memahami materi pelajaran, membentuk kerjasama yang baik, dan saling membantu antar anggota kelompok dalam memecahkan suatu masalah.

\section{Daftar Pustaka}

Alice Rodrigues and Maurícia Oliveira. (2014). The Role Of Critical Thinking In Physics Learning. Centre for Educational Research and Department of Education School of Sciences University of Lisbon Campo Grande, C6, Piso 1 1749-016 Lisbon Portugal.

Arinawati, Eni. (2014). Pengaruh Model Pembelajaran Discovery Learning Terhadap Hasil Belajar Matematika Ditinjau Dari Motivasi Belajar. PGSD FKIP Universitas Sebelas Maret Surakarta.

Balım, A., G. (2009). The Effects of Discovery Learning on Students' Success and Inquiry Learning Skills. Egitim ArastirmalariEurasian Journal of Educational Research, 35, 1-20.

Depdiknas. (2005). Landasan Teori dalam Pengembangan Metode Pengajaran. Materi Pelatihan Terintegrasi Ilmu Pengetahuan Alam. Jakarta: Depdiknas Dirjen Pendasmen Direktorat Pend. Lanjutan Pertama.

Ennis, R.H. (1985). Goals for A Critical Thiking Curriculum. Costa, A.L. (Ed). Developing Minds A Resource Book for Teaching Thinking. Alexandra, Virginia: Assosiation for Supervisions and Curriculum Development (ASCD).

Hasanah, Nove. (2015). Kritik Terhadap Kelemahan Discovery Learning. diakses 5 Desember 2015.2 (tersedia) http://www.referensiguru.com/2015/03/kri tik-kelemahan-discoverylearning.html\#.VoxlxP197IU.

Ilahi, T M. (2012). Pembelajaran Discovery Strategy \& Mental Vocational Skill. Jogjakarta: DIVA Press

Javier A. Pulgar Neira \& Iván R. Sánchez Soto. (2013). Creativity and Physics Learning as Product of the Intervention with Conceptual Maps and Gowin's V Diagram. Creative Education. 4 (2A), 2013, 13-20.
Khabibah, S. (2006). Pengembangan Model Pembelajaran Matematika dengan Soal Terbuka untuk Meningkatkan Kreativitas Siswa Sekolah Dasar. Disertasi Surabaya: Program Pascasarjana Unesa.

Kemendikbud. (2013). Materi Pelatihan Guru, Implementasi Kurikulum 2013. Jakarta: Kementerian Pendidikan dan Kebudayaan.

Melani, R. (2012). Pengaruh Metode Guided Discovery Learning Terhadap Sikap Ilmiah dan Hasil Belajar Kognitif Biologi Siswa SMA Negeri 7 Surakarta Tahun Pelajaran 2011/2012. Pendidikan Biologi FKIP UNS.

Roestiyah, N.K. (1998). Strategi Belajar Mengajar. Jakarta: Rineka Cipta.

Sayekti, Ika candra. (2012). Pembelajaran IPA Menggunakan Pendekatan Inkuiri Terbimbing Melalui Metode Eksperimen dan Demonstrasi Ditinjau dari Kemampuan Analisis dan Sikap Ilmiah Siswa. Jurnal Inkuiri Universitas Sebelas Maret ISSN: 2252-7893. 1 (2) 2012.

Slavin, E. (1994). Educational Psychology: Theory and Practice. Massachusesttes: Allyn and Bacon Publishers.

Undang-Undang Nomor: 20 Tahun 2003 Tentang Sistem Pendidikan Nasional Bab II Pasal 3 
JURNAL INKUIRI

ISSN: 2252-7893, Vol. 6, No. 3, 2017 (hal 17-28)

http://jurnal.uns.ac.id/inkuiri 